\title{
AGENDA PENGEMBANGAN PERBANKAN SYARIAH UNTUK MENDUKUNG SISTEM EKONOMI YANG SEHAT DI INDONESIA: EVALUASI, PROSPEK DAN ARAH KEBIJAKAN
}

\author{
Mulya Siregar \\ Biro Perbankan Syariah - Bank Indonisia
}

\begin{abstract}
Astract
Even though shariah banking has been legally exist in Indonesia since 1992, its development still face some constraints Actually, the development of shariah banking is an soundness of national integral part of developing banking system and strengthening the economic fundamental. So, a good cooperation among stakeholder of shariah banking is strongly needed a market driven, fair treatment, gradual and sustainable, and Islamic values oriented policy are important paradigm for developing a sound shariah banking system. Besides evaluating economic performance of shariah bank and predicting its prospect in the future, this paper also discuss the paradigm, direction and strategic policy for developing shariah banking in Indonesia.
\end{abstract}

\section{PENDAHULUAN}

Eksistensi bank syariah di Indonesia secara formal telah dimulai sejak tahun 1992 dengan diberlakukannya UU No.7 Tahun 1992 tentang Perbankan. Namun, harus diakui bahwa UU tersebut belum memberikan landasan hukum yang cukup kuat terhadap pengembangan bank syariah karena masih menggunakan istilah bank bagi hasil. Pengertian bank bagi hasil yang dimaksudkan dalam UU tersebut belum sesuai dengan cakupan pengertian bank syariah yang relatif lebih luas dari bank bagi hasil. Dengan tidak adanya pasal-pasal dalam UU tersebut yang mengatur bank syariah, maka hingga tahun 1998 belum terdapat ketentuan operasional yang secara khusus mengatur kegiatan usaha bank syariah.

Amandemen terhadap UU No. 7 tahun 1992 yang melahirkan UU No. 10 tahun 1998 yang secara eksplisit menetapkan bahwa bank dapat beroperasi berdasarkan prinsipprinsip syariah. Kemudian, UU No. 23 tahun 1999 tentang Bank Indonesia juga menetapkan bahwa Bank Indonesia dapat melakukan pengendalian moneter berdasarkan prinsip-prinsip syariah. Keberadaan kedua UU tersebut telah mengamanahkan Bank Indonesia untuk menyiapkan perangkat ketentuan dan fasilitas penunjang lainnya yang mendukung operasional bank syariah sehingga memberikan landasan hukum yang lebih kuat dan kesempatan yang lebih luas bagi pengembangan perbankan syariah di Indonesia, yaitu dengan dikeluarkannya sejumlah ketentuan operasional dalam bentuk SK Direksi BI/Peraturan Bank Indonesia. Kedua UU tersebut selanjutnya menjadi dasar hukum bagi keberadaan dual banking system di Indonesia, yaitu adanya dua sistem perbankan (konvensional dan syariah) secara berdampingan dalam memberikan pelayanan jasa perbankan bagi masyarakat.

Upaya pengembangan perbankan syariah di Indonesia tidak semata hanya merupakan konsekuensi dari UU No. 10/1998 dan UU No. 23/1999 tetapi juga merupakan bagian dari upaya penyehatan sistem perbankan yang bertujuan meningkatkan daya tahan perekonomian nasional. Krisis ekonomi yang 
terjadi sejak pertengahan 1997 membuktikan bahwa bank yang beroperasi dengan prinsip syariah dapat bertahan di tengah gejolak nilai tukar dan tingkat suku bunga yang tinggi. Kenyataan tersebut ditopang oleh karakteristik operasi bank syariah yang melarang bunga (riba), transaksi yang bersifat tidak transparan (gharar) dan spekulatif (maysir). Dengan kenyataan tersebut, pengembangan perbankan syariah diharapkan dapat meningkatkan ketahanan sistem perbankan nasional yang pada gilirannya juga diharapkan dapat meningkatkan ketahanan ekonomi nasional di masa mendatang. Ketahanan ekonomi nasional yang sedemikian rupa dapat menciptakan perekonomian yang tangguh, yaitu perekonomian yang pertumbuhan sektor keuangannya sejalan dengan pertumbuhan sektor riil.

Dalam upaya pengembangan perbankan syariah tersebut disadari masih terdapat sejumlah permasalahan yang perlu segera diatasi, baik dalam jangka pendek, menengah, maupun panjang. Belum lengkapnya peraturan dan infrastruktur bagi bank syariah merupakan salah satu permasalahan mendasar yang perlu segera diatasi agar bank syariah dapat beroperasi secara optimal sesuai dengan karakteristiknya. Sejumlah ketentuan yang ada belum sesuai dengan nature of business bank syariah yang tidak mengenal suku bunga dan kegiatan spekulasi serta mengutamakan prinsip kemitraan dan keadilan. Dengan demikian perlu segera disusun peraturan dan infrastruktur yang berdasarkan penelitian (research-based regulations) dan diberlakukan dengan pentahapan yang sesuai perkembangan perbankan syariah. Pentingnya pengaturan perbankan syariah didasarkan pada pertimbangan bahwa bank syariah merupakan bagian dari sistem perbankan yang mempunyai sejumlah perbedaan karakteristik usaha dan sistem operasi dibandingkan dengan bank konvensional. Disamping itu, pengaturan yang bersifat spesifik dalam operasional perbankan syariah diperlukan untuk menjamin terpenuhinya prinsip-prinsip syariah (comply to sharia principles). Urgensi penyempurnaan pengaturan bagi perbankan syariah menjadi penting mengingat ketentuan yang ada saat ini belum sepenuhnya dapat mengakomodir kegiatan usaha perbankan syariah.

Selanjutnya, harus disadari bahwa lengkapnya peraturan dan infrastruktur saja belum cukup untuk menjamin suksesnya bank syariah dalam mendekatkan (linkages) sektor keuangan dengan sektor riil. Sejumlah permasalahan lain masih ditemui dalam upaya pengembangan perbankan syariah, misalnya relatif rendahnya pemahaman masyarakat terhadap operasional perbankan syariah dan terbatasnya tenaga ahli perbankan syariah berpengaruh terhadap potensi permintaan dan penawaran. Disamping itu, relatif terbatasnya jaringan kantor (network) bank syariah menyebabkan masih terbatasnya jangkauan bank syariah dalam melayani masyarakat. Keberadaan institusiinstitusi pendukung agar perbankan syariah dapat beroperasi secara optimal juga dirasakan belum memadai. Di lain pihak, sejumlah isu yang berkaitan dengan perkembangan teknologi dan inovasi ragam produk bank syariah memerlukan pengaturan yang memadai agar stabilitas sistem perbankan syariah dapat terwujud.

Perkembangan perbankan syariah nasional tidak terlepas dari pengaruh globalisasi sektor jasa keuangan. Sejumlah isu pokok yang berkaitan dengan perbankan syariah internasional memerlukan perhatian Bank Indonesia agar perbankan syariah nasional dapat pula menjadi lembaga keuangan yang dapat diterima secara internasional. Isu pokok tersebut antara lain adalah: (i) pembentukan organisasi dan mekanisme pasar keuangan syariah internasional atau International Islamic Financial Market (IIFM) yang diharapkan dapat mendukung efisiensi pengelolaan dana secara internasional sedang dalam proses finalisasi, dan (ii) 18

IQTISAD Journal of Islamic Economics, Vol. 3, No. 1, Muharram 1423 H/Maret 2002 
negara anggota IMF saat ini sedang mempersiapkan pembentukan Islamic Financial Services Board (IFSB), lembaga internasional yang akan mengeluarkan prudential regulation bagi bank syariah.

Untuk mengetahui sejauh mana pengembangan perbankan syariah dapat mendukung perekonomian yang tangguh, dalam makalah ini akan akan diawali dengan evaluasi pengembangan perbankan syariah pada bagian kedua dan pada bagian ketiga mencoba melihat prospek industri perbankan syariah. Selanjutnya secara berurutan, pada bagian keempat, kelima, dan keenam membahas arah kebijakan, paradigma dan nilai-nilai, dan kebijakan strategis pengembangan perbankan syariah dimasa datang. Akhirnya, pada bagian ketujuh disampaikan kesimpulan sebagai penutup.

\section{EVALUASI PENGEMBANGAN PERBANKAN SYARIAH}

Kebijakan pengembangan perbankan syariah kedepan harus dilandasi pemahaman kondisi aktual dan isu-isu pokok yang dihadapi bank syariah. Kelengkapan peraturan dan infrastruktur merupakan permasalahan mendasar yang perlu segera diatasi dalam jangka pendek karena merupakan prasyarat bagi beroperasinya bank syariah. Hal lain adalah relatif rendahnya tingkat pemahaman masyarakat terhadap operasional bank syariah yang akan menentukan perkembangan bank syariah di masa mendatang. Selain itu, perkembangan perbankan syariah juga ditentukan oleh minat investor untuk masuk ke industri perbankan syariah yang akan ditentukan oleh kinerja para bankir syariah dalam mengelola banknya. Selanjutnya, perkembangan kelembagaan dan indikator keuangan perbankan syariah merupakan hal penting yang harus dipantau secara berkala dan merupakan input berharga dalam menentukan langkah-langkah pengembangan perbankan syariah. Akhirnya, perkembangan bank syariah pada tingkat internasional perlu dipahami untuk memetakan posisi yang telah dicapai oleh perbankan syariah di Indonesia.

\section{Peraturan dan Infrastruktur}

Pada tahap awal, landasan hukum bagi pengembangan perbankan syariah adalah UU No. 7 tahun 1992 yang mengizinkan bank untuk memberikan pinjaman kepada nasabah dengan prinsip bagi hasil. Sejak tahun 1992-1998 dapat dikatakan tidak banyak kemajuan dalam perkembangan perbankan syariah di Indonesia terutama karena belum ada landasan hukum yang jelas mengenai keberadaan bank syariah. Dengan lahirnya UU No. 10 tahun 1998 dan UU No. 23 tahun 1999 keberadaan bank syariah diakui secara eksplisit dan memberikan landasan hukum yang lebih kuat bagi Bank Indonesia dalam pengembangan perbankan syariah. Namun, harus disadari bahwa UU No. 10 tahun 1998 yang mengatur keberadaan bank syariah hanya dalam beberapa pasal belumlah cukup sebagai landasan hukum bagi pengembangan perbankan syariah di masa yang akan datang. Sehubungan dengan hal tersebut, kebutuhan terhadap landasan hukum yang berdiri sendiri dirasakan cukup mendesak khususnya dengan semakin pesatnya perkembangan bank syariah. Oleh karena itu, perlu dipersiapkan UU Perbankan Syariah yang dapat menjadi payung bagi semua ketentuan teknis dan operasional bank syariah. Menarik untuk dicermati sebagai bahan perbandingan, ketika Malaysia akan memulai pengembangan bank Islam pada tahun 1983, pemerintah dan parlemen Malaysia dengan penuh komitmen menetapkan Islamic Banking Act sebagai landasan hukum yang terpisah dari UU untuk bank konvensional.

Pengaturan perbankan di Indonesia, tidak terkecuali bank syariah, adalah dalam upaya meningkatkan ketahanan sistem perbankan melalui penyempurnaan peraturan dan infrastruktur. Agar bank syariah dapat beroperasi secara optimal diperlukan 
kelengkapan peraturan dan infrastruktur yang dapat menjamin bank syariah dikelola dengan cara-cara yang sesuai prinsip syariah dan kehati-hatian bank. Pada saat ini telah ada tujuh ketentuan pelaksanaan bagi bank syariah, yaitu tiga ketentuan yang mengatur kelembagaan dan jaringan kantor bank syariah, dan empat ketentuan mengenai pengaturan penyelenggaraan kliring lokal bagi BUS, UUS dan juga BUK; ketentuan mengenai Giro Wajib Minimum bagi BUS maupun UUS; pengaturan tata cara penempatan dana pada SWBI; serta satu ketentuan mengenai infrastruktur PUAS.

Diluar ketentuan-ketentuan tersebut di atas, ketentuan lainnya seperti Kualitas Aktiva Produktif (KAP), Penyisihan Penghapusan Aktiva Produktif (PPAP), Capital Adequacy Ratio (CAR), Batas Maksimum Pemberian Kredit (BMPK), Posisi Devisa Netto (PDN), Tingkat Kesehatan Bank, dan Transparansi Kondisi Keuangan Bank serta ketentuan mengenai Laporan Bulanan Bank-bank masih menggunakan ketentuan yang berlaku bagi bank konvensional. Selain itu, terdapat juga ketentuan yang hanya berlaku bagi bank konvensional, yaitu Fasilitas Pendanaan Jangka Pendek (FPJP) dan Fasilitas Likuiditas Intrahari (FLI), sehingga fungsi Bank Indonesia sebagai the lender of last resort masih terbatas bagi bank konvensional.

Perangkat ketentuan yang menjadi acuan bagi beroperasinya perbankan syariah seharusnya disusun dengan memperhatikan business nature bank syariah, dengan tetap memperhatikan prinsip-prinsip kehati-hatian bank. Berdasarkan pertimbangan tersebut dan dengan tujuan agar perbankan syariah dapat beroperasi secara optimal sesuai dengan keunikannya maka ketentuan-ketentuan perbankan syariah perlu disempurnakan secara bertahap sesuai dengan skala prioritasnya. Terdapat sejumlah ketentuan yang perlu disempurnakan, misalnya pengaturan GWM yang masih menyamakan
DPK bank syariah yang bersifat investasi (ekuitas) dengan DPK bank konvensional yang bersifat kewajiban (liabilities). Penyempurnaan ketentuan kelembagaan dan jaringan kantor bagi UUS juga perlu dilakukan dengan tujuan agar masyarakat yang membutuhkan layanan bank syariah dapat terlayani. Guna mengefektifkan peran bank syariah dalam menggerakkan sektor riil perlu diatur portofolio aktiva produktif bank syariah agar tidak didominasi oleh aset yang tidak memiliki keterkaitan dengan sektor riil. Selain itu, perlu diatur pola kerjasama (ta'awun) antara BPRS, BUS dan UUS untuk berperan dalam pembiayaan Usaha Kecil dan Menengah (UKM) dan masyarakat pedesaan. Semua rencana ketentuan tersebut akan diatur secara bertahap sesuai dengan kebutuhan dan perkembangan bank syariah. Penyusunan ketentuan-ketentuan tersebut di atas sangat tergantung pada selesainya Pernyataan Standar Akuntansi Keuangan Perbankan Syariah (PSAKS) dan Pedoman Akuntansi Perbankan Syariah Indonesia (PAPSI) yang saat ini sedang dalam tahap finalisasi oleh Ikatan Akuntansi Indonesia bekerjasama dengan Bank Indonesia. Jika PSAKS dan PAPSI tersebut telah diberlakukan maka Indonesia akan menjadi negara pertama yang ikatan profesinya telah mengeluarkan dan mengadopsi sistem akuntansi syariah. PSAKS dan PAPSI akan menjadi pedoman akuntansi bagi perbankan syariah di Indonesia sehingga keberadaannya akan membantu Bank Indonesia dalam melakukan penyempurnaan ketentuanketentuan bagi perbankan syariah.

\section{Perkembangan Kelembagaan dan Indikator Keuangan}

Tahun 1992 merupakan tahun yang menggembirakan dalam sejarah perkembangan bank syariah di Indonesia yang ditandai dengan berdirinya bank syariah pertama yaitu PT. Bank Muamalat Indonesia, Tbk (BMI). Namun, dalam periode 1992-1998 
tidak terdapat hal berarti dalam perkembangan bank syariah yang disebabkan oleh beberapa hal:

- rendahnya pengetahuan dan kesalah pahaman masyarakat mengenai bank syariah;

- belum tersedianya ketentuan pelaksana terhadap operasional bank syariah;

- terbatasnya jaringan kantor perbankan syariah; dan

- kurangnya sumber daya insani (SDI) yang memiliki keahlian perbankan syariah.

Perkembangan bank syariah mulai terasa sejak dilakukan amandemen terhadap UU No. 7/1992 menjadi UU No. 10/1998 yang memberikan landasan operasi yang lebih jelas bagi bank syariah. Sebagai tindak lanjut UU tersebut, Bank Indonesia mulai memberikan perhatian lebih serius terhadap pengembangan perbankan syariah, yaitu pada bulan April 1999 membentuk satuan kerja khusus yang menangani penelitian dan pengembangan bank syariah (Tim Penelitian dan Pengembangan Bank Syariah dibawah Direktorat Penelitian dan Pengaturan Perbankan) yang menjadi cikal bakal Biro Perbankan Syariah yang dibentuk pada 31 Mei 2001. Sebagai hasil dari upaya pengembangan perbankan syariah yang dilaksanakan secara intensif sejak dikeluarkannya UU No. 10 tahun 1998 maka pertumbuhan perbankan syariah relatif pesat sejak tahun 1999. Pada awal tahun 1999 jumlah bank syariah baru terdapat 1 bank umum syariah dengan 9 kantor cabang serta 76 BPRS, maka pada posisi saat ini (Februari 2002) telah terjadi pertumbuhan menjadi 2 bank umun syariah penuh dan 4 bank konvensional yang membuka KC Syariah dengan jumah kantor cabang 49 kantor serta 82 BPRS. Sementara itu pada periode yang sama jumlah aset dan dana pihak ketiga yang dihimpun oleh bank syariah telah bertumbuh lebih dari empat kali lipat.
Selama satu tahun terakhir ini (20002001) indikator keuangan bank syariah menunjukkan perkembangan yang cukup menggembirakan. Aset bank syariah sampai dengan Desember 2001 berjumlah Rp2,72 triliun $(0.25 \%$ dari aset perbankan nasional) atau tumbuh $26.2 \%$ dibandingkan akhir 2000. Dana masyarakat yang dikelola oleh bank syariah berjumlah Rp1,81 triliun (0.23\% dari total Dana Pihak Ketiga perbankan nasional) dan pembiayaan yang diberikan berjumlah Rp2,05 triliun (0.57\% dari total kredit perbankan nasional). Meskipun banyak bank konvensional yang kesulitan dalam memberikan kredit, namun bank syariah tetap aktif menyalurkan pembiayaan yang terlihat pada angka Financing to Deposit Ratio (FDR) ${ }^{1}$ yang relatif tinggi (berkisar pada angka 113,5\%). Kualitas aktiva produktif bank syariah yang terlihat dari nilai PPAP dan Non Performing Financings (NPFs) menunjukkan angka yang relatif baik bila dibandingkan dengan bank konvensional. Posisi akhir tahun 2001 menunjukkan bahwa NPFs bank syariah hanya $7,41 \%$ dari total pembiayaan yang diberikan. Kemampulabaan (profitability) bank syariah juga menunjukkan perkembangan yang menggembirakan. Laba tahun berjalan bank syariah terus meningkat hingga berjumlah Rp 90,06 miliar pada Desember 2001.

Dari pengamatan terhadap perkembangan perbankan syariah yang telah ada menunjukkan bahwa hingga saat ini minat bank syariah dalam pembiayaan masih terfokus pada pembiayaan murabahah. Pangsa pembiayaan murabahah berkisar pada angka $65 \%$ dari total pembiayaan dan cenderung masih mengarah kepada pembiayaan untuk keperluan konsumtif. Di sisi lain, pembiayaan mudharobah dan musyarakah hanya berkisar pada $24 \%$ dan 2,2\% (akhir 2001). Rendahnya

\footnotetext{
${ }^{1}$ Dalam bank konvensional dikenal sebagai LDR, penghitungan FDR merupakan rasio antara pembiayaan yang diberikan terhadap DPK yang dihimpun.
} 
pembiayaan mudharobah disebabkan tingginya risiko pembiayaan dimana bank syariah menyediakan dana $100 \%$ dan bila terjadi kerugian maka bank yang harus menanggung kerugian tersebut. Pembiayaan mudharobah dan musyarakah yang merupakan quasi equity financing sangat cocok untuk pembiayaan kegiatan produktif khususnya kepada usaha kecil dan menengah (UKM) dan masyarakat pedesaan yang sudah sejak lama mengenal sistem bagi hasil. Namun karena adanya anggapan pembiayaan untuk masyarakat pedesaan dan UKM mengandung resiko yang cukup besar dan membutuhkan biaya penyaluran pembiayaan yang tinggi, maka penyaluran pembiayaan bank syariah pada kedua hal tersebut belum memuaskan. Walaupun demikian dari sejumlah kegiatan pemeriksaan bank yang dilakukan Bank Indonesia menunjukkan mulai adanya sedikit pergeseran pembiayaan perbankan syariah kepada UKM. Selanjutnya, guna memperkecil resiko pembiayaan mudharobah dan musyarakah, bank syariah harus didukung oleh lembaga pembiayaan penjaminan seperti yang disampaikan Chapra (1996) ${ }^{2}$ : The risk may be reduced by introducing a loan guarantee scheme underwritten partly by the government and partly by the commercial banks. Hal yang sama dikemukakan Choudhury $(2001)^{3}$, bahwa untuk menghubungkan sektor riil dengan sektor keuangan melalui pembiayaan mudharobah perlu adanya lembaga penjamin.

\section{Perkembangan Internasional dan Posisi Indonesia}

Dibandingkan dengan negara-negara lain seperti Malaysia yang telah melakukan pengembangan bank syariah sejak 1983 atau bahkan Bahrain yang telah melakukannya sejak 1979, pengembangan bank syariah di

\footnotetext{
${ }^{2}$ Chapra, M. Umer (1996).

${ }^{3}$ Dalam diskusi terbatas dengan Biro Perbankan Syariah di Bank Indonesia pada tanggal 7 Agustus 2001.
}

Indonesia yang dimulai tahun 1992 relatif terlambat. Hal tersebut disebabkan antara lain oleh:

- belum sependapatnya ulama Indonesia mengenai keberadaan bunga bank;

- kurang kondusifnya kondisi sosial politik di Indonesia yang mengakibatkan belum adanya politica lwill pemerintah pada masa itu;

- $\quad$ tanggung jawab moral yang harus dipikul karena mencantumkan label "syariah";

- adanya kendala dasar hukum sehingga belum memungkinkan pengembangan bank syariah karena bank syariah belum dikenal dalam UU No. 14 tahun 1967 tentang Perbankan maupun UU No. 13 tahun 1968 tentang Bank Sentral.

Kondisi terkini perkembangan bank syariah di beberapa negara yang masih menganut dual banking system menunjukkan bahwa tingkat penetrasi bank syariah dalam ukuran total aset bank syariah terhadap total perbankan masih relatif rendah, kecuali di Kuwait yang telah mencapai $30 \%$ pada tahun 2000. Sedangkan penetrasi perbankan syariah di beberapa negara masih dibawah $20 \%$, yaitu Saudi Arabia 12\%, UAE 6\%, Malaysia $6,8 \%$, dan Bahrain $1,3 \%$ pada tahun yang sama. Sedangkan penetrasi perbankan syariah di Indonesia paling rendah, yaitu masih dibawah 1\%, hanya sekitar $0.2 \%$. Selain itu, perkembangan pasar keuangan Islam, baik dalam hal ragam instrumen maupun volume pasar, Indonesia relatif tertinggal dibandingkan dengan negaranegara dimaksud. Indonesia hanya unggul dibandingkan negara-negara tersebut dalam hal jumlah lembaga keuangan syariah saja, khususnya karena keberadaan 82 BPRS.

Perkembangan terakhir perbankan syariah internasional semakin marak dengan adanya beberapa negara (seperti Malaysia, Bahrain, Sudan, Brunei, dan Indonesia beserta IDB) yang telah membentuk International Islamic Financial Market (IIFM). Dengan adanya IIFM tersebut, diharapkan bank-bank syariah 
yang mengalami kelebihan likuiditas tidak hanya tergantung pada instrumen keuangan syariah domestik, tapi dapat juga menempatkan dananya pada pasar tersebut. Adanya pasar tersebut akan dapat mengurangi persoalan rendahnya efisiensi pengelolaan dana bank syariah yang terjadi selama ini. Dalam kerangka IIFM, seberapa jauh bank-bank syariah dapat mengakses pasar tersebut akan sangat tergantung pada performance bank syariah yang menjadi kriteria bagi bank sentral atau otoritas moneter di tiap negara untuk memberikan rekomendasi kepada IIFM Committee agar bank-bank syariah dapat masuk menjadi anggota dalam pasar tersebut. Sehubungan dengan hal tersebut, bank-bank syariah di Indonesia harus segera mempersiapkan diri dengan sebaik-baiknya guna mampu memanfaatkan keberadaan pasar tersebut.

Selanjutnya, dengan semakin berkembangnya lembaga keuangan syariah (LKS) yang telah mencapai 166 LKS yang tersebar di +/- 34 negara dengan total aset mencapai $\$ 137,7$ milyar dan modal $\$ 7,3$ milyar pada tahun 1997, maka diperlukan prudential regulation bagi lembaga-lembaga tersebut. Sehubungan dengan hal tersebut, 18 negara yang memiliki lembaga keuangan syariah di negaranya telah berinisiatif untuk mendirikan Islamic Financial Services Board (IFSB) yang mendapat dukungan dan koordinasi penuh dari International Monetary Fund (IMF). Kehadiran lembaga ini sangat dinantikan karena adanya ketentuan-ketentuan yang berstandard internasional akan menjadi acuan dalam menetapkan prudential regulation bagi bank syariah, pada waktunya lembaga tersebut akan pula menetapkan Risk Management and Regulatory Standard for Islamic Financial Institutions. Kemampuan bank-bank syariah memenuhi ketentuanketentuan yang bertaraf internasional akan berdampak positif terhadap bank syariah karena akan memudahkan bank-bank syariah dalam berperan di tingkat internasional, khususnya dalam memasuki IIFM.

\section{PROSPEK INDUSTRI \\ PERBANKAN SYARIAH}

Prospek perkembangan industri perbankan syariah nasional kedepan antara lain akan dipengaruhi oleh perkembangan permintaan masyarakat dan penyediaan jasa perbankan syariah oleh perbankan dan/atau investor serta faktor-faktor yang mempengaruhi kedua sisi supply dan demand tersebut, seperti upaya public education yang dilakukan oleh berbagai pihak, penyempurnaan regulasi dan dukungan pemerintah dan otoritas perbankan dalam mendorong perkembangan kantor bank syariah. Dari sisi demand dapat dilihat dari seberapa besar kelompok masyarakat yang menginginkan keberadaan dan kesediaan menggunakan jasa perbankan syariah, dan diharapkan demand tersebut akan dapat terus bertambah dengan meningkatnya pemahaman masyarakat Sedangkan dari sisi supply dapat dilihat dari minat investor untuk masuk industri perbankan syariah, perkembangan jaringan kantor dan membaiknya kinerja keuangan dan profesionalisme perbankan syariah.

\section{Demand Side: Persepsi, Preferensi dan Permintaan Masyarakat Terhadap Jasa Bank Syariah}

Perkembangan perbankan syariah di Indonesia akan dipengaruhi oleh kebutuhan atau permintaan masyarakat terhadap layanan jasa perbankan syariah (demand side). Untuk mengetahui kondisi sisi permintaan tersebut telah dilakukan penelitian "Potensi, Preferensi, dan Perilaku Masyarakat terhadap Bank Syariah" di pulau Jawa (tidak termasuk DKI Jaya), Sumatera Barat dan Jambi oleh Bank Indonesia bekerja sama dengan sejumlah Perguruan Tinggi Negeri. Penelitian di Pulau Jawa yang dilaksanakan pada tahun 2000 menunjukkan bahwa $45 \%$ dari responden berpendapat bahwa sistem 
bunga tidak sejalan dengan ajaran agama yang dianut. Sedangkan hasil penelitian di Sumatera Barat pada tahun 2001, 20\% dari responden yang meyakini sistem bunga tidak sesuai dengan ajaran agama. Untuk propinsi Jambi, hasil penelitian tahun 2001 memperlihatkan bahwa 50\% dari responden berpotensi untuk menjadi mitra bank syariah. Angka-angka tersebut dapat digunakan sebagai salah satu ukuran bagi potensi minat masyarakat terhadap layanan bank syariah. Namun, harus disadari bahwa jumlah tersebut dapat naik atau turun yang tergantung pada kinerja perbankan syariah, seperti kualitas pelayanan dan tingkat profitabilitas. Selain itu, keberhasilan bankbank syariah dalam mempromosikan sistem ini kepada semua lapisan masyarakat sangat menentukan minat masyarakat untuk bermitra dengan bank syariah.

Penelitian menunjukkan bahwa persepsi masyarakat terhadap perbankan syariah adalah identik dengan bank bagi hasil. Selain itu, masyarakat menganggap bahwa bank syariah adalah bank yang Islami. Namun, penelitian menemukan opini kurang tepat yang berkembang di masyarakat bahwa bank syariah secara eksklusif hanya khusus untuk umat Islam $(8,1 \%$ responden Jawa Barat). Di sisi lain, juga terdapat pendapat apriori (skeptis) yang menganggap bahwa bank syariah sama saja dengan bank konvensional dan bagi hasil sama saja dengan bunga (10,2\% dan $16,5 \%$ responden Jawa Timur). Sedangkan sebagian besar responden di Jawa Barat (94\%) dan Jawa Tengah $(86,5 \%)$ menilai bahwa sistem bagi hasil adalah sistem yang universal dan dapat diterima karena menguntungkan bank maupun nasabah. Informasi yang dimiliki masyarakat mengenai keberadaan bank syariah relatif tinggi, namun pemahaman terhadap keunikan sistem, produk dan jasa bank syariah secara umum masih relatif rendah.

Kualitas pelayanan dan kedekatan lokasi bank dari pusat kegiatan merupakan faktor dominan yang mempengaruhi preferensi masyakarat Jawa Barat dan Jawa Timur untuk menggunakan jasa bank syariah. Sementara, masyarakat Jawa Tengah lebih didominasi oleh pertimbangan keagamaan dalam menggunakan jasa bank syariah. Temuan tersebut diperkuat dengan informasi bahwa masyarakat non-nasabah bank syariah yang diberi penjelasan sistem, produk dan jasa, serta kehalalan bank syariah memiliki kecenderungan kuat untuk memilih bank syariah.

Penelitian yang dilakukan menunjukkan bahwa persepsi masyarakat terhadap bank syariah sudah cukup baik. Kenyataan tersebut harus terus dipelihara dan bahkan ditingkatkan dengan serangkaian kegiatan public education yang dilakukan secara terprogram dan terintegrasi oleh semua pelaku industri perbankan syariah. Edukasi publik mengenai perbankan syariah sebaiknya tidak semata menggunakan pendekatan emosi keagamaan yang hanya mempromosikan label kehalalan produk bank syariah tetapi harus mencerdaskan masyarakat sehingga memahami manfaat dan keunggulan bank syariah. Konsekuensi logis dari model edukasi tersebut adalah bank syariah dituntut untuk menunjukkan kemampuannya dalam melayani masyarakat. Preferensi masyarakat terhadap bank syariah akan dapat dipertahankan (sustainable) sepanjang bank syariah mengutamakan faktor-faktor yang mempengaruhi preferensi masyarakat seperti kualitas pelayanan, kedekatan lokasi dan konsistensi dalam mengimplementasikan prinsip-prinsip syariah. Bila hal tersebut luput dari perhatian bank syariah, bukan tidak mungkin preferensi masyarakat tersebut akan berubah seiring dengan berjalannya waktu.

\section{Supply Side: Minat Investor untuk Masuk ke Industri Perbankan Syariah}

Minat investor untuk masuk industri perbankan syariah yang ditunjukkan beberapa indikator, seperti: adanya pembukaan bank 
umum syariah baru baik milik domestik maupun milik asing, konversi Bank Umum Konvensional (BUK) menjadi Bank Umum Syariah (BUS), pembukaan Kantor Cabang Syariah (KCS) oleh bank umum konvensional dan adanya pembukaan BPRS baru maupun konversi BPR konvensional menjadi BPRS. Minat untuk mengkonversi BUK menjadi BUS maupun BPR menjadi BPRS harus dilandasi pertimbangan bahwa bank memiliki kemampuan untuk melakukan paradigm shift dan didukung oleh adanya permintaan masyarakat terhadap produk bank syariah. Konversi seharusnya tidak dijadikan sebagai pelarian akibat telah gagal dan tidak sehat sebagai bank konvensional, sehingga proses konversi hanya dapat dilakukan oleh BUK dan BPR yang sehat.

Sampai dengan sat ini (Februari 2002), pemain dalam industri perbankan syariah terdiri dari 2 BUS dan 4 Unit Usaha Syariah (UUS) dari BUK yang seluruhnya memiliki jaringan kantor berjumlah $49 \mathrm{KCS}$, serta 82 BPRS. Peningkatan jumlah pemain dalam industri perbankan syariah terlihat cukup pesat bila dibandingkan dengan keadaan akhir tahun 1999 yang hanya berjumlah 1 BUS dengan $9 \mathrm{KCS}$ dan 76 BPRS. Minat investor untuk membuka kantor bank syariah tidak hanya terbatas di pulau Jawa tetapi juga telah menyebar ke pulau lainnya, antara lain: Sumatera (Banda Aceh, Medan, Padang, Palembang dan Pekanbaru); Kalimantan (Balikpapan dan Banjarmasin); Sulawesi (Makasar); Madura (Pamekasan); dan Irian Jaya (Jayapura). Dengan perkembangan terakhir tersebut jaringan perbankan syariah telah meliputi 18 propinsi. Selain hal tersebut, pada saat ini terdapat sejumlah BUK yang sedang dalam proses perizinan untuk membuka UUS (yaitu Bank BRI dan Bank Danamon). Selain itu, terdapat pula dua bank umum swasta nasional yang telah mengemukakan rencana konversi secara penuh seluruh usahanya menjadi bank syariah dalam waktu dekat. Berdasarkan beberapa indikator tersebut di atas, dapat disimpulkan bahwa minat investor untuk memasuki industri perbankan syariah sejauh ini cukup menggembirakan.

Perluasan jaringan kantor (networking) perbankan syariah diperkirakan akan semakin cepat bila ketentuan pembukaan jaringan kantor disempurnakan. Ketentuan penambahan jaringan kantor yang berlaku saat ini mengatur bahwa untuk menambah kantor kas, kantor cabang pembantu dan KCS maka UUS harus menyediakan gedung kantor untuk masing-masing jenis kantor tersebut. Saat ini ketentuan tersebut sedang dalam proses penyempurnaan dengan harapan UUS dapat membuka kantor dibawah KCS (unit syariah) dengan menumpang sementara pada KCK sepanjang memenuhi sejumlah persyaratan. Dengan penyempurnaan ketentuan tersebut, UUS dimungkinkan untuk tidak menyediakan gedung kantor ketika membuka unit syariah baru, namun dalam jangka waktu tertentu unit syariah tersebut harus menjadi KCS.

Hal lain yang perlu diperhatikan dalam pengembangan perbankan syariah adalah keberadaan mitra bank syariah yaitu lembagalembaga keuangan syariah, seperti asuransi syariah, reksadana syariah, baitul mal wattamwil (BMT), perusahaan modal ventura syariah dan lain-lain ${ }^{4}$. Keberadaan LKS-LKS tersebut perlu mendapatkan perhatian dari pemerintah dalam bentuk pengaturan yang jelas, sehingga LKS tersebut dapat beroperasi dengan baik. Adanya pengaturan yang jelas bagi LKS tersebut akan memudahkan bagi bank

\footnotetext{
${ }^{4}$ Perkembangan LKS non-bank sangat pesat selama dua tahun terakhir, pada saat in terdapat \pm 4000 BMT yang beroperasi diseluruh tanah air, terdapat 3 perusahaan asuransi syariah penuh dan 3 asuransi konvensional yang memiliki kantor cabang syariah, 2 investment management company yang menawarkan reksadana syariah, dan JSX per pertengahan tahuan 2000 telah memperkenalkan Jakarta Islamic Index yang dijadikan benchmark investasi pasar modal secara syariah
} 
syariah dalam melakukan kerja sama, yang pada gilirannya dapat meningkatkan minat investor dalam membuka bank syariah.

\section{ARAH KEBIJAKAN PENGEMBANGAN PERBANKAN SYARIAH DI INDONESIA}

\section{Pentingnya Pengembangan Perbankan Syariah}

Sektor perbankan sebagai intermediary institution antara pihak yang kelebihan dana (surplus spending unit) dengan pihak yang membutuhkan dana (deficit spending unit) memiliki posisi strategis dalam perekonomian nasional. Dengan demikian peranan perbankan nasional termasuk perbankan syariah perlu ditingkatkan dalam hal penghimpunan dan penyaluran dana masyarakat, serta penyediaan layanan jasa perbankan lainnya. Sejalan dengan upaya restrukturisasi perbankan untuk membangun kembali sistem perbankan yang sehat dalam rangka mendukung program pemulihan ekonomi nasional, maka salah satu upaya yang dilakukan untuk mengoptimalkan fungsi perbankan adalah pengembangan perbankan syariah. Disamping pertimbangan tersebut di atas terdapat sejumlah alasan lain bagi pentingnya pengembangan perbankan syariah, yaitu:

- Pemenuhan kebutuhan masyarakat yang menginginkan layanan jasa perbankan syariah. Berdasarkan penelitian yang dilaksanakan oleh BI bekerjasama dengan tiga universitas pada tahun 2000 diperoleh kesimpulan bahwa $45 \%$ dari 4000 sample di pulau Jawa (tidak termasuk DKI Jaya) berpandangan bahwa bunga bank adalah tidak sejalan dengan ajaran agama. Dengan keberadaan perbankan syariah yang berdampingan dengan perbankan konvensional maka mobilisasi dana masyarakat dapat dilakukan lebih luas, terutama dari segmen yang selama ini belum tersentuh oleh perbankan konvensional.
- Terbukanya peluang pembiayaan bagi kegiatan usaha berdasarkan prinsip kemitraan (partnership). Konsep yang diterapkan adalah hubungan kerjasama investasi yang harmonis (mutual investor relationship) yang berbeda dengan pola hubungan debitur dan kreditur yang antagonis (debtor to creditor relationship) pada perbankan konvensional.

- Produk dan jasa perbankan yang ditawarkan memiliki sejumlah keunggulan berupa peniadaan pembebanan bunga yang berkesinambungan (perpetual interest effect), pembatasan kegiatan spekulasi dan mengutamakan kegiatankegiatan yang mewujudkan keterkaitan antara sektor keuangan dengan sektor riil (linkages between financial sector and real sector), pembiayaan ditujukan kepada usaha-usaha yang lebih memperhatikan nilai-nilai etika dan moralitas.

\section{Misi, Visi, dan Tujuan Pengembangan Perbankan Syariah}

Dalam upaya pengembangan perbankan syariah disadari perlu adanya kejelasan arah kebijakan dan pengembangan guna seluruh stake holder perbankan syariah mengetahui ke arah mana perbankan syariah akan dikembangkan. Untuk hal tersebut diperlukan adanya misi, visi dan tujuan pengembangan perbankan syariah karena ketiga hal tersebut merupakan pre-requisite bagi sebuah kebijakan perbankan syariah. Tanpa ketiga hal tersebut, dikhawatirkan akan terjadi halhal sebagai berikut:

- kebijakan pengembangan perbankan syariah yang disusun menjadi kurang jelas arahnya

- kebijakan pengembangan perbankan syariah yang disusun menjadi tidak sesuai dengan prinsip-prinsip syariah;

- dampak ikutannya adalah fungsi pengawasan perbankan syariah menjadi kurang memadai; dan 
- operasional perbankan syariah menjadi kurang optimal karena ketidaksesuaian antara kebijakan dengan nature of business dari bank syariah.

\section{Misi}

Misi pengembangan perbankan syariah di Indonesia adalah mewujudkan iklim yang kondusif untuk pengembangan perbankan syariah yang sehat dan istiqamah terhadap prinsip-prinsip syariah. Mengingat otoritas pengaturan dan pengawasan perbankan syariah sampai dengan saat ini masih berada di Bank Indonesia, maka fungsi-fungsi yang saat ini dilakukan oleh Bank Indonesia meliputi:

- melakukan kajian-kajian terhadap operasi perbankan syariah, preferensi masyarakat, dan hal lain yang diperlukan untuk menjamin bank syariah beroperasi secara optimal;

- menyiapkan peraturan dan infrastruktur agar bank syariah dapat beroperasi sesuai dengan nature of business-nya;

- melakukan pengawasan dan pemeriksaan terhadap operasi bank syariah untuk menjamin bank syariah comply to sharia and prudential principles; dan

- mengeluarkan izin untuk beroperasinya bank syariah.

Berdasarkan misi tersebut di atas jelas terlihat bahwa keberhasilan pengembangan perbankan syariah di Indonesia tidak semata hanya merupakan tugas Bank Indonesia tetapi juga ditentukan oleh peran aktif stake holders perbankan syariah lainnya dalam mewujudkan lingkungan yang kondusif agar bank syariah dapat beroperasi secara optimal. Keberhasilan pengembangan perbankan syariah juga sangat ditentukan oleh kemampuan bank-bank syariah memberikan excellent services dalam melayani masyarakat yang membutuhkan produk dan jasa perbankan syariah.
Visi

Karakteristik bank syariah adalah menekankan aspek keadilan, menyeimbangkan aspek moral dan material, dana yang terkumpul harus dikelola untuk memperoleh nilai tambah guna menciptakan kesejahteraan, harta dipergunakan untuk memakmurkan bumi demi kemaslahatan umat, adanya pelarangan kegiatan usaha yang bersifat spekulatif atau pentingnya keberadaan underlying assets dalam setiap transaksi, dan hubungan antara nasabah dengan bank syariah adalah kemitraan (partnership). Berdasarkan hal tersebut maka perbankan syariah sangat terkait dengan sektor riil. Dengan demikian, visi pengembangan perbankan syariah adalah terwujudnya perbankan syariah yang mampu menggerakkan sektor riil melalui kegiatan pembiayaan berbasis ekuitas dalam kerangka tolong menolong (ta'awun) dan menuju kebaikan (fastabiqul khairat) guna mencapai kemashlahatan ummat (rahmatan lil alamin).

\section{Tujuan}

Pengembangan perbankan syariah memiliki tujuan jangka pendek, menengah dan panjang. Dalam jangka pendek pengembangan perbankan syariah bertujuan untuk mewujudkan perbankan syariah yang mampu memenuhi kebutuhan masyarakat yang menginginkan layanan bank syariah di seluruh penjuru Indonesia. Hal tersebut belum sepenuhnya terlaksana karena adanya kendala peraturan yang belum memungkinkan beroperasinya bank syariah secara optimal. Kemampuan melayani masyarakat masih terbatas di beberapa propinsi karena belum lengkapnya informasi mengenai peta kebutuhan masyarakat akan produk dan jasa bank syariah serta adanya ketentuan yang kurang kondusif mengenai penyebaran jaringan kantor bank syariah.

Tujuan jangka menengah adalah terwujudnya bank syariah yang mampu lebih berperan dalam menggerakkan sektor riil. 
Sampai dengan saat ini pembiayaan berbasis ekuitas yang diberikan perbankan syariah masih relatif terbatas, namun di lain pihak pembiayaan murabahah masih mendominasi portofolio aset perbankan syariah. Hal tersebut disebabkan by its nature pembiayaan mudharobah tidak mengutamakan jaminan dan kerugian sepenuhnya menjadi tanggungan bank syariah, sehingga menempatkan bank pada posisi menghadapi risiko yang relatif lebih tinggi dibandingkan pembiayaan murabahah. Hal lain yang perlu memperoleh perhatian adalah peranan perbankan syariah dalam pembiayaan sektor pedesaan (rural sector) dan Usaha Kecil dan Menengah (UKM) yang selama ini relatif terbatas aksesnya kepada pembiayaan perbankan konvensional. Opini yang berkembang di kalangan bankir adalah relatif tingginya risiko dan biaya pengelolaan pembiayaan sektor pedesaan dan UKM. Seandainya perbankan syariah tidak dapat dengan optimal memainkan peran tersebut maka implikasinya adalah semakin terabaikannya "masyarakat bawah" (grassroots) dalam memperoleh pembiayaan perbankan. Mannan (2000) menyatakan "... Don't call a bank as an Islamic Bank, if the Islamic Bank does not want to serve the grassroots". Untuk menjembatani dua kepentingan tersebut di atas perlu kehadiran lembaga pendukung seperti Lembaga Penjaminan Pembiayaan Syariah yang dapat mengurangi risiko bank terhadap pembiayaan mudharobah dan grassroots.

Tujuan jangka panjang dari pengembangan perbankan syariah adalah terwujudnya bank syariah yang dapat beroperasi dengan lebih efisien. Saat ini, dalam pengelolaan likuiditas bank syariah masih relatif kurang efisien akibat adanya kelebihan likuiditas dan belum banyaknya instrumen keuangan syariah yang dapat dimanfaatkan sebagai alternatif penempatan. Indikasi terjadinya kelebihan likuiditas bank syariah terlihat dari penempatan bank syariah pada SWBI yang mencapai Rp. 364,9 milyar atau 12,86\% dari portofolio aset (Desember 2001) bank syariah. Dalam hal ini, keberadaan lembaga pendukung seperti Special Purpose Company (SPC) sangat diharapkan untuk melakukan sekuritisasi aset-aset berjangka panjang dengan cara yang sesuai prinsip syariah. Dengan keberadaan lembaga tersebut, pada waktunya akan tersedia instrumen-instrumen keuangan syariah sebagai alternatif penempatan dana bagi bank syariah. Selain itu, hadirnya lembaga tersebut juga akan memungkinkan bank syariah untuk dapat berkiprah dalam perdagangan instrumen keuangan syariah di pasar internasional, khususnya ketika IIFM telah beroperasi.

\section{PARADIGMA KEBIJAKAN \\ DAN NILAI-NILAI SYARIAH}

Dalam rangka pengembangan industri perbankan syariah maka proses penyusunan kebijakan oleh otoritas perbankan perlu dipayungi oleh sekumpulan paradigma kebijakan. Hal tersebut diperlukan untuk menjamin konsistensi peran dan tugas otoritas perbankan dalam pengembangan perbankan syariah. Di sisi lain, terwujudnya industri perbankan syariah yang tumbuh sesuai harapan dan memiliki kemampuan untuk menerapkan kebijakan yang dikeluarkan oleh otoritas perbankan, memerlukan persyaratan berupa penerapan nilai-nilai syariah oleh perbankan syariah. Dengan demikian, paradigma kebijakan dan nilainilai syariah merupakan prasyarat yang harus terpenuhi dalam upaya pengembangan perbankan syariah.

\section{Paradigma Kebijakan}

Upaya pengembangan perbankan syariah yang masih dalam tahap awal memerlukan sekumpulan paradigma kebijakan yang dapat dijadikan sebagai acuan dalam penyusunan kebijakan, ketentuan dan pengembangan infrastruktur perbankan syariah. Paradigma kebijakan yang diperlukan untuk menjamin 
konsistensi peran dan tugas otoritas perbankan dalam pengembangan perbankan syariah adalah:

- Market driven. Pengembangan jaringan kantor bank syariah diserahkan sepenuhnya kepada kehendak pasar yaitu interaksi antara masyarakat yang membutuhkan produk dan jasa perbankan syariah dengan investor atau lembaga perbankan yang menyediakan pelayanan jasa perbankan syariah. Bank syariah harus mampu membaca kehendak pasar dan memberikan pelayanan terbaiknya. Namun pelayanan bank syariah terhadap kehendak pasar bukan berarti bank syariah harus bersedia untuk didikte oleh pasar, melainkan bank syariah harus mampu: untuk berpegang teguh pada prinsip-prinsip syariah, menunjukkan keunggulannya dan mendidik masyarakat akan keunikan bank syariah. Dalam hal ini peran otoritas perbankan (Bank Indonesia) lebih ditekankan pada penciptaan perangkat ketentuan perbankan yang dapat mendukung terlaksananya kegiatan usaha bank syariah yang sehat, efisien dan sejalan dengan prinsip syariah.

- Fair treatment. Pengaturan dan pengembangan perbankan syariah dilaksanakan dengan tidak memberikan perlakuan-perlakuan khusus terhadap industri perbankan syariah. Pengaturan dan ketentuan yang diterapkan pada perbankan syariah akan disesuaikan dengan nature of business-nya. Dengan demikian, konsekuensi dari hal tersebut adalah akan sangat wajar jika terdapat peraturan dan ketentuan yang mungkin tidak sama antara bank syariah dan bank konvensional.

- Gradual and sustainable approach. Pengembangan perbankan syariah baik dari sisi kelembagaan maupun pengaturan dilaksanakan secara bertahap dan berkelanjutan. Penyusunan ketentuan dan pengembangan infrastruktur perbankan syariah tentunya tetap harus didasarkan pada realitas yang dihadapi, khususnya dalam lingkungan yang masih belum sepenuhnya ideal menurut syariah. Pengabaian terhadap kenyataan ini akan menempatkan upaya pengembangan perbankan syariah pada posisi yang tidak membumi dan dapat berakibat kontraproduktif terhadap pertumbuhan industri perbankan syariah. Berkaitan dengan hal ini, disadari bahwa terdapat kesulitan-kesulitan untuk segera mewujudkan kondisi ideal dari suatu sistem perbankan syariah yang baru berkembang. Penyempurnaan ketentuan dan infrastruktur pendukung perbankan syariah dilaksanakan secara bertahap dengan memperhatikan urgensi dan prioritas dari sejumlah tugas yang harus dilaksanakan.

- Secara konsisten sesuai prinsip syariah (comply to sharia principles) dan standar internasional. Pengaturan dan pengembangan infrakstruktur perbankan syariah harus memenuhi prinsip-prinsip syariah dan mengacu pada standar internasional. Tingkat pemenuhan kedua hal ini harus disesuaikan dengan stage perkembangan perbankan syariah nasional, bila tidak memungkinkan menerapkan regulasi dan infrastruktur yang sepenuhnya ideal, maka pilihan kebijakan harus ditetapkan walaupun belum sepenuhnya sempurna. Namun, usaha-usaha perbaikan ketentuan dan infrastruktur harus diusahakan terus menerus untuk mendekati kesempurnaan.

\section{Implementasi Nilai-nilai Syariah Dalam Operasi Perbankan Syariah}

Terwujudnya industri perbankan syariah yang tumbuh sesuai harapan dan memiliki kemampuan untuk menerapkan kebijakan yang dikeluarkan oleh otoritas perbankan, memerlukan persyaratan berupa 
penerapan nilai-nilai syariah dalam operasi perbankan syariah. Nilai-nilai tersebut dapat ditinjau dari perspektif mikro dan makro. Pengertian nilai-nilai syariah dalam perspektif mikro adalah bahwa dana umat yang terakumulasi dalam perbankan syariah harus dikelola secara jujur (siddiq), benar dan objektif (tabligh), terpercaya (amanah) dan profesional (fathanah). Sedangkan pengertian nilai-nilai syariah dalam perspektif makro adalah bahwa keberadaan perbankan syariah harus memiliki kontribusi dalam membentuk masyarakat yang memiliki kecenderungan: siap berinvestasi dan tidak menumpuk harta (kaidah zakat), tidak memastikan masa depan (adanya uncertainty) dan dapat menerima risiko (kaidah pelarangan riba), dan selalu berkaitan dengan sektor riil (adanya underlying transaction) dalam kegiatan investasinya (kaidah pelarangan judi atau maisir) dan untuk melakukan transaksi secara jelas dan transparan (kaidah pelarangan gharar).

\section{Nilai-Nilai Syariah dalam Perspektif Mikro}

- Nilai siddiq menghendaki adanya pengelolaan bank syariah dengan moralitas yang menjunjung tinggi nilai kejujuran. Dengan nilai ini pengelolaan dana umat akan dilakukan dengan mengedepankan cara-cara yang diperkenankan (halal) serta menjauhi cara-cara yang meragukan (subhat) terlebih lagi yang bersifat dilarang (haram).

- Nilai tabligh menghendaki penyampaian berbagai hal dengan benar dan objektif khususnya mengenai operasional bank syariah. Hal ini sangat penting dalam rangka proses edukasi masyarakat pengguna jasa perbankan syariah. Bank syariah dalam melakukan sosialisasi sebaiknya tidak hanya mengedepankan kehalalan produknya semata, tetapi juga harus mampu mengedukasi masyarakat sehingga mengetahui keunggulan bank syariah yang pada dasarnya lebih adil.
Adanya tingkat pemahaman yang baik dari pengguna jasa perbankan syariah diyakini akan lebih memudahkan masyarakat menerima perbankan syariah.

- Nilai amanah menghendaki adanya rasa saling percaya antara pihak yang memiliki modal (shahibul maal) dengan pihak pengelola dana investasi (mudharib). Rasa saling percaya akan mendorong terbentuknya suatu kerjasama yang diinginkan sekaligus akan mengkondisikan iklim yang memungkinkan investor untuk secara ikhlas menerima risiko.

- Nilai fathanah menghendaki adanya pengelolaan secara cerdik (profesional). Dengan moralitas fathanah diharapkan pengelolaaan dana umat dapat dilakukan dalam koridor profesionalisme serta dapat dipertangungjawabkan secara profesional pula. Termasuk di dalam pengertian profesional adalah pelayanan yang penuh dengan kecermatan dan kesantunan (ri'ayah) serta penuh rasa tanggung jawab (mas'uliyah).

Nilai-Nilai Syariah dalam Perspektif Makro

- Kaidah zakat dapat digunakan untuk mengkondisikan perilaku masyarakat yang menyukai investasi. Dengan terwujudnya perilaku tersebut diharapkan akan dapat membantu terwujudnya perekonomian berbasis ekuitas (equitybased economy) yang relatif lebih kuat dibandingkan debt-based economy Penerapan kaidah tersebut dapat diterapkan pada keberadaan rekening wadiah dan mudharobah. Rekening wadiah adalah rekening yang tidak menanggung risiko sehingga rekening ini dapat dikenakan zakat (harta atau maal). Sedangkan rekening mudharobah adalah rekening yang menanggung risiko dan mencerminkan adanya perputaran dana sesuai dengan konsep ekonomi Islam sehingga pokok rekening ini tidak perlu dikenakan zakat. Namun, apabila 
rekening tersebut menerima bagian keuntungan dapat dikenakan zakat penghasilan. Adanya dua rekening yang memiliki perbedaan sifat tersebut beserta konsekuensinya, diharapkan akan mendorong terbentuknya kecenderungan masyarakat untuk selalu berinvestasi.

- Kaidah pelarangan riba tercermin dari kegiatan bank syariah yang menolak riba dan cenderung menganjurkan bagi hasil di dalam berbagai produknya. Diharapkan keberadaan produk-produk nonriba ini akan mendorong terbentuknya kecenderungan masyarakat untuk tidak bersikap memastikan dan bergeser ke arah sikap untuk berani menghadapi risiko. Hal ini sesuai dengan ekonomi Islam bahwa tidak ada penerimaan tanpa menghadapi risiko (no return without risk).

- Kaidah pelarangan judi atau maisir tercermin dari kegiatan bank syariah yang melarang investasi yang tidak memiliki kaitan dengan sektor riil. Kondisi ini pada gilirannya akan membentuk kecenderungan masyarakat untuk menghindari judi di dalam aktivitas investasinya.

- Kaidah pelarangan gharar tercermin dari setiap transaksi yang dilakukan oleh bank syariah harus menghindari ketidak jelasan, sehingga transparansi dalam berbagai kegiatan perbankan syariah sangat diutamakan.

\section{KEBIJAKAN STRATEGIS \\ PENGEMBANGAN \\ PERBANKAN SYARIAH}

Mengacu pada misi, visi dan tujuan pengembangan perbankan syariah maka kebijakan pengembangan perbankan syariah harus ditujukan untuk mengatasi persoalanpersoalan pada demand side dan supply side perbankan syariah. Strategi tersebut dilakukan dengan pertimbangan bahwa keberhasilan pertumbuhan industri perbankan syariah tergantung pada penawaran dan permintaan akan produk dan layanan perbankan syariah. Beberapa hal mendasar yang menentukan ketersediaan produk dan jasa perbankan syariah adalah sumber daya insani (SDI) yang berkualitas yang dapat memberikan excellent services, kemampuan perbankan syariah menarik modal (investasi), adanya pengembangan infrastruktur, serta penerapan regulasi dan pengawasan oleh otoritas yang dapat menjamin terciptanya kompetisi yang sehat. Dari sisi permintaan, hal yang perlu diperhatikan adalah terpenuhinya asas manfaat yang dapat diukur dari kepuasan konsumen terhadap produk dan layanan bank syariah, serta tersebarnya informasi asas manfaat tersebut apa adanya (transparan) kepada konsumen sasaran.

Dalam penetapan kebijakan-kebijakan strategis, perlu disadari bahwa kegiatan pengembangan perbankan syariah tidak dapat dilaksanakan sekaligus dalam satu tahapan. Sehubungan dengan hal tersebut, untuk 10 tahun ke depan perlu ditetapkan kebijakankebijakan strategis jangka pendek, jangka menengah dan jangka panjang guna mencapai tujuan yang sesuai dengan rentang waktunya. Pada dasarnya kebijakan strategis jangka pendek meliputi periode tahun 2002 sampai dengan 2004 dengan fokus penyusunan berbagai ketentuan yang dibutuhkan bank syariah dan penyelenggaraan edukasi publik untuk meningkatkan pemahaman masyarakat akan bank syariah. Selanjutnya, kebijakan strategis jangka menengah dimulai pada tahun 2004 sampai dengan 2008 dengan fokus kebijakan untuk lebih memberdayakan bank syariah dalam menggerakkan sektor riil. Sedangkan kebijakan strategis jangka panjang dimulai tahun 2006 sampai dengan 2011 dengan fokus kebijakan untuk meningkatkan efisiensi perbankan syariah agar dapat berperan di tingkat internasional. 


\section{Kebijakan Strategis Jangka Pendek (2002-2004)}

1. Penyusunan ketentuan-ketentuan perbankan syariah

Untuk menjamin bank syariah dapat beroperasi dengan optimal sesuai nature of business-nya diperlukan kelengkapan sejumlah ketentuan seperti:

- PSAKS dan PAPSI (kerjasama BI dengan IAI) yang menjadi faktor penentu bagi ketentuan lainnya dan pengembangan infrastruktur perbankan syariah.

- Kualitas Aktiva Produktif (KAP).

- Penyisihan Penghapusan Aktiva Produktif (PPAP).

- Capital Adequacy Ratio (CAR).

- Batas Maksimum Pemberian Kredit (BMPK).

- Posisi Devisa Netto (PDN).

- Tingkat Kesehatan Bank.

- Transparansi Kondisi Keuangan Bank.

- Ketentuan mengenai Laporan Bulanan Bank-bank.

- Fasilitas Pembiayaan Jangka Pendek (FPJP) dan Fasilitas Likuiditas Intrahari (FLI) bagi bank syariah.

- Ketentuan GWM akan disempurnakan agar lebih sesuai dengan prinsipprinsip syariah dan dilengkapi dengan ketentuan baru mengenai secondary reserves atau Liquid Asset Ratio (LAR).

- Penyempurnaan ketentuan kelembagaan dan jaringan kantor bagi UUS juga perlu dilakukan agar pertumbuhan jaringan kantor dapat berlangsung lebih cepat.

- Pengaturan portofolio aktiva produktif dari bank syariah guna mengantisipasi semakin banyaknya instrumen keuangan syariah.

- Mekanisme kerjasama antara BUS maupun UUS dengan BPRS guna meningkatkan pelayanan bagi masyarakat pedesaan dan UKM.

- Guna menjamin lebih kuatnya dasar hukum pengembangan perbankan syariah perlu disiapkan kajian akademis mengenai kemungkinan diundangkannya UU mengenai perbankan syariah yang terpisah dari UU perbankan.

2. Mendorong terbentuknya Forum Komunikasi (communication board)

Program edukasi publik yang selama ini dilakukan Bank Indonesia bertujuan untuk menginformasikan keberadaan perbankan syariah bagi masyarakat dan menumbuhkan pemahaman akan manfaat yang dapat diberikannya. Program edukasi dilakukan dengan kelompok sasaran adalah ulama, praktisi, akademisi, mahasiswa dan masyarakat umum. Selama ini, program edukasi cenderung bersifat pasif menunggu permintaan masyarakat dari daerah tertentu. Berdasarkan beberapa penelitian di Jawa dan Sumatera Barat dapat disimpulkan bahwa program edukasi yang dilakukan belum efektif yang terlihat dari banyaknya masyarakat yang belum mengenal bank syariah. Dengan kenyataan tersebut, program edukasi publik terhadap perbankan syariah harus dilakukan secara aktif dengan kelompok sasaran yang lebih luas (mencakup pelajar-pelajar mulai dari SD) yang dapat dilakukan baik melalui media massa, maupun dengan tatap muka mendatangi masyarakat di daerah-daerah potensial.

Program edukasi publik akan memberatkan bila tetap dilaksanakan oleh Bank Indonesia yang tugas utamanya adalah regulator dan pengawas. Dalam jangka pendek, bank-bank syariah akan didorong untuk membentuk Communication Board sebagai lembaga independen yang bertugas mengedukasi masyarakat secara aktif. Dengan demikian, kegiatan

IQTISAD Journal of Islamic Economics, Vol. 3, No. 1, Muharram 1423 H/Maret 2002 
edukasi publik yang selama ini dikerjakan oleh Bank Indonesia dapat dialihkan kepada lembaga independen tersebut selambat-lambatnya pada akhir 2004.

3. Melanjutkan peningkatan kualitas SDI

Sebagai konsekuensi dari akan bertambahnya jaringan kantor bank syariah, maka kebutuhan terhadap SDI juga akan meningkat. Oleh karena itu, pelatihan perbankan syariah tetap perlu dilaksanakan bagi pegawai bank-bank yang berminat untuk beroperasi berdasarkan prinsip syariah. Demikian juga halnya dengan pegawai Bank Indonesia mengingat banyak ketentuan perbankan syariah yang terkait dengan sejumlah satuan kerja di Bank Indoensia. Pelatihan ini juga perlu dilakukan bagi mahasiswa maupun akademisi di perguruan tinggi dengan harapan mahasiswa tersebut merupakan potensi SDI yang dapat bekerja di bank syariah atau minimal menjadi pengguna jasa bank syariah. Sedangkan pelatihan bagi dosen diperlukan agar masyarakat kampus dapat bersiap dengan program studi mengenai bank syariah maupun ekonomi syariah, yang pada gilirannya dapat menghasilkan sarjana-sarjana dengan keahlian di bidang perbankan dan ekonomi syariah.

Dalam upaya mewujudkan bankirbankir syariah yang istiqamah terhadap nilai-nilai syariah maka pelatihan, khususnya mengenai aspek nilai-nilai Islam, tetap diperlukan bagi SDI bankbank syariah yang telah beroperasi. Pelatihan aspek syariah khususnya dasar-dasar fiqih juga dibutuhkan bagi pengawas bank syariah. Sedangkan bagi Dewan Pengawas Syariah (DPS) perlu diberikan pelatihan mengenai aspek perbankan sehingga anggota DPS yang bertugas mengawasi aspek syariah dapat mengerti mekanisme kerja sebuah bank.

4. Menggalang kerjasama dengan berbagai instansi terkait
Untuk lebih memberdayakan perbankan syariah dibutuhkan mitra dari lembaga-lembaga keuangan syariah lainnya. Oleh karena itu perlu dijalin kerjasama dengan berbagai lembaga terkait seperti Departemen Keuangan, Departemen Koperasi, Departemen Perdagangan dan Industri serta lembagalembaga terkait lainnya. Melalui kerjasama ini akan tercipta kesadaran dari berbagai lembaga khususnya lembaga pemerintah akan pentingnya peranan mereka untuk dapat berkontribusi dalam mengembangkan ekonomi syariah umumnya dan perbankan syariah khususnya. Diharapkan melalui kerjasama yang baik akan dilahirkan ketentuanketentuan yang sesuai bagi LKS-LKS seperti BMT, asuransi syariah, perusahaan modal ventura syariah, reksa dana syariah dan lain-lain, yang merupakan mitra bagi bank-bank syariah.

5. Melanjutkan penelitian preferensi dan perilaku konsumer terhadap bank syariah

Penelitian ini dapat dilanjutkan pada propinsi-propinsi yang potensial bagi pengembangan perbankan syariah seperti Kalimantan Selatan, Sulawesi Selatan, Sumatera Selatan, Sumatera Utara, Banten, dan Riau. Hal ini perlu dilakukan untuk melengkapi peta potensi pengembangan perbankan syariah yang dapat dimanfaatkan oleh bank-bank yang akan konversi maupun membuka KCS.

6. Mempersiapkan teknologi informasi

Saat ini teknologi informasi yang dimiliki BPRS sangat terbatas, maka untuk mempercepat monitoring kegiatan BPRS diperlukan komputerisasi yang dilengkapi dengan teknologi informasi yang memungkinkan Bank Indonesia dapat mengikuti perkembangan BPRS dari hari kehari. Sedangkan untuk BUS dan UUS sebaiknya segera dipersiapkan teknologi informasi yang memungkinkan 
Bank Indonesia dapat melakukan real time supervision.

\section{Kebijakan Strategis Jangka Menengah (2004-2008)}

1. Mempersiapkan Lembaga Penjamin Pembiayaan Syariah.

Kehadiran lembaga penjamin akan sangat menentukan kemampuan bank syariah dalam menggerakkan sektor riil melalui alokasi pembiayaan mudharobah ke daerah pedesaan dan UKM. Lembaga ini yang akan melakukan investigasi mengenai perilaku mitra yang dapat dipercaya (amanah) dalam mengelola dana dan memiliki kemampuan berusaha. Bila perilaku amanahnya diragukan dan kemampuannya rendah tidak akan dijamin dalam memperoleh pembiayaan. Nasabah-nasabah yang masih rendah kemampuannya, diberikan pelatihan sehingga eligible untuk memperoleh pembiayaan bank syariah dan dijamin oleh lembaga tersebut. Bank syariah akan memperoleh kembali dananya bila terjadi kegagalan nasabah karena negligence ataupun moral failure. Namun, bila kegagalan karena normal business loss maka bank turut menanggung kerugian tersebut.

2. Mendorong terbentuknya Islamic Trade Center.

Lembaga ini merupakan lembaga penyedia informasi mengenai skimskim pembiayaan maupun investasi yang dimiliki bank syariah dan informasi kegiatan produktif sektor riil yang mungkin dibiayai oleh bank syariah. Penyediaan informasi yang menggunakan teknologi informasi ini diharapkan dapat menciptakan linkages antara sektor riil dan sektor keuangan syariah.

3. Memberdayakan pengawasan aspek syariah
Selama ini pengawasan aspek syariah (sharia audit), yang dilakukan oleh Dewan Pengawas Syariah (DPS) yang ditunjuk oleh DSN, dirasakan belum optimal. Beberapa hal yang diperkirakan menjadi penyebab adalah kurangnya independensi DPS terhadap bank syariah dan terbatasnya alokasi waktu anggota DPS. Dalam kondisi demikian, perlu dipikirkan agar anggota DPS dapat independen sehingga dapat menjalankan fungsinya dengan efektif. Disamping itu perlu dipertimbangkan kemungkinan sentralisasi pengawasan aspek syariah dan berada pada DSN, sehingga pengawasan aspek syariah dilakukan secara periodik dan sejalan dengan kegiatan program pengawasan yang dilaksanakan oleh Bank Indonesia. Alternatif lain, adalah perlu dipersiapkan syariah auditor yang merupakan ahli-ahli syariah yang mempunyai kemampuan perbankan syariah dan memiliki independensi seperti akuntan publik.

\section{Kebijakan Strategis Jangka Panjang (2006-2011)}

1. Mempersiapkan pembentukan Special Purpose Company (SPC)

Kebijakan strategis jangka panjang yang sangat mendasar adalah mempersiapkan terbentuknya SPC yang memiliki fungsi sebagai berikut:

- memastikan keterkaitan antara sekuritisasi dengan aktivitas produktif di sektor riil guna penciptaan pasar primer;

- menciptakan pasar sekunder; dan

- menyediakan layanan bagi partisipan pasar (paying agents and custodian).

Keberadaan SPC harus dipersiapkan setelah perbankan syariah memiliki peran yang besar dalam pembiayaan sektor riil. Adanya pertumbuhan pembiayaan sektor riil yang cukup beragam memungkinkan dilakukan 
sekuritisasi aset-aset syariah. Adanya SPC akan dapat memperbaiki efisiensi pengelolaan likuiditas, karena dana idle dapat diperkecil.

2. Mempersiapkan pembentukan Biro Ekonomi Syariah

Sesuai dengan UU No. 23 tahun 1999, bahwa tugas pengaturan dan pengawasan bank akan diserahkan secara bertahap kepada Lembaga Pengawas Jasa Keuangan (LPJK), maka hal tersebut juga akan berlaku bagi pengaturan dan pengawasan bank syariah. Sehubungan dengan baru akan dilengkapinya regulasi dan infrastruktur perbankan syariah, maka sebaiknya penyerahan tugas pengaturan dan pengawasan perbankan syariah dilakukan setelah tercapainya tujuan jangka menengah pada tahun 2008, yaitu bank syariah sudah semakin berperan dalam pembiayaan sektor riil. Konsekuensi dari penyerahan tugas tersebut adalah kegiatan pengaturan, pengawasan dan perizinan bank syariah akan beralih dari Biro Perbankan Syariah di Bank Indonesia kepada LPJK. Dalam konteks tersebut perlu dipertimbangkan untuk mempersiapkan berdirinya Biro Ekonomi Syariah, yang bertugas untuk melanjutkan penelitian dan pengembangan kebijakankebijakan moneter berdasarkan prinsipprinsip syariah. Hal tersebut menjadi penting karena diperkirakan transmisi kebijakan moneter pada saat itu sudah dapat dilakukan melalui bank-bank syariah.

\section{PENUTUP}

Untuk menjamin keberhasilan upaya pengembangan perbankan syariah diperlukan kerja sama semua stake holders perbankan syariah, yang diharapkan dapat menghasilkan sinergi bagi tumbuh kembangnya industri perbankan syariah yang sesuai dengan harapan. Dalam upaya mewujudkan sinergi tersebut diperlukan kesamaan arah dan pandang mengenai arah dan kebijakan pengembangan perbankan syariah nasional. Meskipun harapan terhadap perbankan syariah demikian besarnya, namun perlu disadari bahwa pengembangan perbankan syariah harus dilakukan secara bertahap dan membumi, melalui kebijakan strategis jangka pendek, menengah dan panjang.

Dengan paradigma kebijakan yang ada, maka dapat dimaklumi bahwa kebijakan pengembangan perbankan syariah harus mempertimbangkan market driven, fair treatment, gradual and sustainable, dan sesuai dengan prinsip-prinsip syariah. Dengan adanya paradigma kebijakan diharapkan akan lahir kebijakan-kebijakan pengembangan perbankan syariah yang objektif. Disamping itu, perbankan syariah harus dapat mengimplementasikan nilai-nilai syariah dengan sebaik-baiknya agar dapat menggerakkan demand masyarakat melalui produk, dan layanan perbankan syariah (perspektif mikro) serta dapat menciptakan perilaku investasi yang konsisten (perspektif makro).

Pengembangan perbankan syariah -dalam konteks diversifikasi sistem perbankan tentu akan meningkatkan daya tahan perekonomian nasional-- akan mendukung terciptanya perekonomian yang tangguh karena sesuai dengan nature bank syariah yang mengutamakan adanya underlying asset dalam setiap transaksi akan menciptakan harmonisasi pertumbuhan sektor riil dan sektor keuangan. Alur pikir seperti ini kiranya jangan disalah artikan bahwa pengembangan perbankan syariah bertujuan untuk menggantikan sistem perekonomian yang ada, melainkan pada dasarnya guna melayani masyarakat yang membutuhkan pelayanan jasa perbankan syariah. Sungguh naif bangsa ini, bila ada masyarakat yang menginginkan pelayanan perbankan syariah tidak terlayani, hanya karena adanya kekhawatiran bahwa kegiatan 
pengembangan tersebut merupakan agenda Islamisasi ekonomi Indonesia ataupun adanya prasangka buruk bahwa prinsip syariah hanya dijadikan kedok untuk berbisnis. Pengembangan perbankan syariah tidak dilakukan melalui decree, dan tidak juga karena emosi keagamaan, melainkan pengembangan perbankan syariah memiliki dasar hukum UU yang jelas dan sepenuhnya berada dalam koridor ekonomi yang berdasarkan market driven yaitu adanya demand dan supply jasa perbankan syariah, sehingga jelas pengembangan ini bukan dalam kerangka gerakan politik maupun agama. Pengembangan seperti ini, harus dilakukan secara bertahap melalui kebijakan strategis guna pencapaian tujuan jangka pendek, menengah dan panjang. Untuk itu harus ditunjang dengan penelitian-penelitian guna melahirkan regulasi yang objektif yang mencerminkan fair treatment sehingga bank syariah dapat beroperasi secara optimal dan juga ditunjang dengan sosialisasi yang mendidik masyarakat agar dalam memilih bank syariah karena paham akan manfaatnya, bukan melulu karena emosi keagamaan.

Selanjutnya, bila dibelakang hari masyarakat merasakan manfaat dari lebih adilnya bank syariah dan perbankan syariah dapat menunjukkan jati dirinya dalam menunjang perkembangan sektor riil sehingga keberadaan bank syariah menciptakan kemakmuran bangsa, kemudian masyarakat lebih cenderung memilih bank syariah yang pada gilirannya menghendaki perekonomian seluruhnya berdasarkan prinsip syariah, tentu dalam hal ini pemerintah harus sepenuhnya mendengar aspirasi masyarakat dan sewajarnya memiliki political will untuk mengimplementasikan perekonomian syariah. Artinya perekonomian yang tangguh tidak akan dapat tercipta dengan mengubah secara drastis sistem perekonomian yang ada menjadi sistem perekonomian berdasarkan prinsipprinsip syariah dan dengan mengabaikan kesiapan sisi demand maupun supply.
Akhirnya, dapat disimpulkan bahwa pengembangan perbankan syariah yang dapat menciptakan perekonomian yang tangguh adalah pengembangan yang harus melalui beberapa tahapan, berdasarkan kehendak pasar, fair treatment dan tetap harus konsisten dengan prinsip-prinsip syariah.

\section{DAFTAR PUSTAKA}

Al Rajhi, Abdullah Sulaiman, (1999). Islamic Banks: Technology and Global Challenges and Opportunities. Proceedings Third Harvard University Forum on Islamic Finance, October 1, 1999. Cambridge, MA: HIFIP.

Arifin, Zainul, (1998). Strategi Pengembangan Perbankan Bagi Hasil di Indonesia. Sespibi: Bank Indonesia.

Chapra, M. Umer, (1986). Towards a Just Monetary System. Leicester, UK: The Islamic Foundation. (1992). Islam and Economic Challenges, Leicester, UK: The Islamic Foundation.

(1996). Monetary Management in an Islamic Economy. Islamic Economic Studies, Vol. 4, No. 1. (2000). The Future of Economics: An Islamic Perspective. Leicester, UK: The Islamic Foundation.

Choudhury, Masudul Alam, (1997). Money in Islam: A Study in Islamic Political Economy. London, UK: TJ International Ltd, Padstow, Cornwall. (2000). The Islamic Worldview. London, UK: Kegan Paul International Limited. , (2001). Growth of Islamic Banking. Saudi Commerce \& Economic Review, June - No. 86.

, (2001). The Nature of Money and Monetary Policy for Islamic Economic Integration, Seminar Paper in Bank Indonesia. Jakarta: Bank Indonesia.

IQTISAD Journal of Islamic Economics, Vol. 3, No. 1, Muharram 1423 H/Maret 2002 
Choudry, Nurun N. dan Abas Mirakhor, (1997). Indirect Instruments of Monetary Control in an Islamic Financial System. Islamic Economic Studies, Vol. 4 No. 2.

Dar, Humayon A. dan John R. Presley, (1999). Toward A Greater Contribution of the Shariah Bank for Indonesian Economy, Seminar Paper in Bank Indonesia. Jakarta: Bank Indonesia.

Karuvelil, Koshy Zacharia, (1999). Islamic Finance: Sustaining Success Proceedings Third Harvard University Forum on Islamic Finance, October 1, 1999. Cambridge, MA: HIFIP.

Khan, Iqbal Ahmad, (1999). Developing the Country Framework for Islamic Finance. Proceedings Third Harvard
University Forum on Islamic Finance, October 1, 1999. Cambridge, MA: HIFIP.

Mannan, M. A. (2000). Islamic Economics: Theory and Practice, Seminar Paper in Bank Indonesia. Jakarta: Bank Indonesia.

Mills, Paul S. dan John R. Presley, (1997). The Prohibition of Interest in Western Literature. Workshop on Islamic Economics: Islamic Foundation.

Muslehuddin, Mohammad, (1974). Sistem Perbankan Dalam Islam. Terjemahan oleh Aswin Simamora (1990), Jakarta: Rineka Cipta.

Siddiqi, Nejatullah (1981). Banking without Interest. Lahore, PK: Islamic Publications Ltd. 